\title{
Celebrating Ten Years of Arctic Review
}

\author{
Øyvind Ravna ${ }^{1}$ and Nigel Bankes ${ }^{2}$ \\ ${ }^{1}$ UiT The Arctic University of Norway; ${ }^{2}$ University of Calgary, Canada
}

2020 represents a milestone for Arctic Review on Law and Politics as it is 10 years since the first, slender issue of the journal was launched at the university bookstore in Tromsø, Norway, on 14 April 2010. In a manner of speaking, the journal has left its innocent childhood and entered a more challenging adolescence. This anniversary year provides an opportunity to both look back in time and to present some thoughts about the future. It is also a golden opportunity to present an anniversary anthology of insightful articles.

\section{The story}

The idea of a journal focusing on law and legal issues related to the High North was conceived in the years of 2008 and 2009, inspired by the new High North policy of the Stoltenberg government, closer academic co-operation with Russian partner institutions, growing interest in the rights of indigenous peoples epitomized by the adoption of the United Nations Declaration on the Rights of Indigenous Peoples in 2007, as well as the acknowledgment that climate change could lead to significant legal and political challenges in the Arctic. Knowledge brought to the fore in The Arctic Human Development Report a few years earlier, also contributed to a new overall picture of the circumpolar Arctic. ${ }^{1}$

The mission of the journal, as stated in the first editorial, was to provide a forum to discuss and challenge questions of law and politics in an Arctic and academic context. The terms law and politics were understood in a wide sense, encompassing not only research in the legal and political sciences, but also disciplines such as economics, sociology, human geography, and social anthropology. The aim of the journal was thus to provide new insights and a deeper understanding of fundamental issues related to the Arctic and the High North, and become a forum for academic discussion on sustainable development in the North. It was also announced that the journal should deal with a range of issues including: resource management, devolution of powers, jurisdictional matters and environmental concerns. It was also a

(C) 2020 Øyvind Ravna \& Nigel Bankes. This is an Open Access article distributed under the terms of the Creative Commons Attribution-NonCommercial 4.0 International License (https://creativecommons.org/licenses/by-nc/4.0/), allowing third parties to share their work (copy, distribute, transmit) and to adapt it, under the condition that the authors are given credit, that the work is not used for commercial purposes, and that in the event of reuse or distribution, the terms of this license are made clear. 
goal that the journal should provide for academic discussion related to indigenous peoples' issues.

The Arctic Review quickly gained attention. On 24 August 2010, the journal received accreditation from the Norwegian Association of Higher Education Institutions (UHR) as a scientific journal. Later that year, the journal was evaluated by the Nordic Board for Periodicals in the Humanities and the Social Sciences (NOP-HS), in connection with an application for funding, and given an excellent evaluation.

Regarding the content of Arctic Review, while the journal has not published thematic issues, it has nevertheless published articles on connected topics related to the Arctic and High North, linking them through editorials, several with guest editors. Such topics have included: integrated ocean management, legal and political challenges in the governance of natural resources, fisheries, cross-border co-operation between academics, Indigenous issues, fisheries law and the law of the sea, Greenland, the Polar Code and coast guard cooperation.

The Arctic Review has also seen other developments. In 2014, our faithful publisher for the first five volumes, Gyldendal Akademisk, informed us that the Review had not received the subscription numbers needed for an economically sustainable operation, and despite the support received from NOP-HS, there was no basis for continuing without additional subsidies. This led to a hectic process to identify supporters to ensure that the journal would survive. Both the Faculty of Law at UiT The Arctic University of Norway, other faculties and the UiT university administration were invited to contribute. After some negotiation, the Faculty of Law assumed financial responsibility for the journal in exchange for the publishing rights and committing the journal to Open Access publishing, based on the collection of publication fees.

However, it remained to find a new publisher for the journal. According to the University's statute, this had to be done through tenders. Co-Action Publishing, already an experienced Open Access publisher, won the tender. Co-Action transferred the publishing-agreement to their Norwegian partner Cappelen Damm, which was ready to publish the journal through the Nordic Open Access Scholarly Publishing (NOASP) platform. Late autumn 2014 was spent turning the paper journal into a digital periodical with a new publisher. This "new publisher" is still with the journal - and behind us we have nearly six years of constructive collaboration.

The first Open Access issue of Arctic Review on Law and Politics, making the journal accessible worldwide, was published in March 2015. In the editorial of that volume, we wrote that Open Access publishing hopefully would establish a pattern for how new research and knowledge within the social sciences and jurisprudence could be communicated effectively. We also expressed the hope that by transitioning to Open Access, the goals staked out on an early spring day in 2009, now rested on a firm foundation. During its first five years, the journal had already published more than 50 original peer-reviewed articles of the kind announced in 2010, based 
on contributions not only from Scandinavia, but also from Canada, Russia, New Zealand, the USA and the EU. In addition, the Arctic Review had also become a widely used channel for publishing articles on indigenous people's rights and issues.

In 2014, the three law faculties in Norway nominated the Arctic Review for level 2 in Norwegian Centre for Research Data's register of scientific publication channels. Level 2 is the highest ranking an academic journal or publisher can reach in Norway, and is limited to publications considered leading in a broad professional setting and not constituting more than 20 percent of total scientific publications in their field. The nomination was followed up by The Norwegian Association of Higher Education Institutions (UHR), which in December 2014 approved the Arctic Review at level 2, effective 1 January 2016.

That endorsement provided additional motivation for the editors to further raise the level of the journal. The first issue at level 2 was published in May 2016 with five original articles including topics such as consultation processes in Greenland regarding the mining industry, an article on the 1933 PCIJ's East Greenland (Norse occupation) case, the Polar Code and coast guard cooperation. The new digital platform has also meant that the review process is fully documented at all levels.

Although the journal turned to Open Access publishing, it continued the tradition of two issues per year, a natural structure when it was printed on paper and delivered to subscribers by mail. Publishing online and Open Access, however, the editors soon realised that there was no particular reason to continue this tradition. From January 2017, two years after Arctic Review on Law and Politics went Open Access, the journal celebrated the consequences of digital innovation by henceforth publishing articles as soon as they have been through the peer-review process and approved by the editors; in other words, continuous publishing. Continuous publishing was justified by the benefits offered to both our authors and readers. The authors' articles are published without unnecessary delay, while the readers gain faster access to new knowledge and the latest research in law and political sciences related to the High North and neighboring areas.

The Open Access platform, the adoption of continuous publishing and the higher scientific ranking, have all contributed to researchers and scientists from institutions and disciplines choosing to use the Review for dissemination of research findings. Among the many who have done so we mention University of Aberdeen, UK, The Institute of World Economy and International Relations of the Russian Academy of Sciences (IMEMO), Norwegian Institute of International Affairs, University of Ferrara, Italy, University of Turin; CDRP, University of Paris Nanterre, Balsillie School of International Affairs, University of Waterloo, Canada, Department of Geography and Economic History, Umeå University, Department of Architecture, Harvard University, USA, Institute of History and Law, Khakas State University, Russia, Norwegian Institute for Defence Studies (IFS), Norwegian Defence University College, Norwegian Institute for Water Research (NIVA), Akvaplan-niva, Norway and Centre for Independent Social Research, Russia. The editors are also pleased that 
Fridtjof Nansen Institute (FNI) has contributed insightful articles throughout the journal's history, continuing with this anniversary issue.

At the beginning of 2020, when the Arctic Review had published 10 volumes, it is with pleasure that the editors can note that 108 original, peer-reviewed articles have been published. In addition, a number of editorials, debate articles, news articles and book reviews have been published during these ten years. If there should be any doubt that the goals staked out in 2009 - to publish articles in the fields of law and politics to provide new insights and a deeper understanding of fundamental issues related to the Arctic and the High North - were met in 2014 or 2015, there can be no doubt that they have been reached in 2020. Nor can it be denied that Arctic Review has become a forum for academic discussion on sustainable development in the North, encompassing not only research on law and political sciences, but also disciplines such as economics, sociology, geography, social anthropology and indigenous law and cultural knowledge.

Unfortunately, the Arctic Review has not only had upswings. Although there are not many downturns to count, it was a setback to the journal when it was deprived of its level 2 ranking among academic journals in law in 2017, with effect from 1 January 2019. It is a comfort, however, that this was not rooted in a perception of a reduction in scientific level, but that there is a limited number of journals within a subject approved at level 2. The downgrade can also be seen as an academic dispute between the law faculties in Norway, where Oslo and Bergen did not see the same need for a law journal focusing on the Arctic, the High North and indigenous peoples, as did Tromsø.

With this anniversary issue, the editors hope to focus on the Arctic Review's role as an Open Access journal and as an important contributor to the dissemination of juridical and social science research and knowledge on the High North, the Arctic and Indigenous peoples. We hope that the next ten years of adolescence will be as useful and fruitful as the first ten years of childhood have been for the Review.

There are many to thank for their support and help throughout the first ten years of the Review. First of all, thanks to researchers and authors who have contributed insightful and original research articles. Without them, there would not be anything to review and publish, and thus no journal. Furthermore, the national editors, the assisting editors and subject editors must be thanked for their invaluable contributions. Likewise, the many guest editors who have enthusiastically contributed editorial work, editors and original articles, also deserve thanks. So do the editorial board, the two publishers, Gyldendal and Cappelen Damm, and the Faculty of Law at UiT.

It is dangerous to mention individual names above others. But there are individuals who deserve a special thank you for their dedicated work for the journal. Anne Birgitte Songe and Katia Stieglitz, representing the two publishers, Timo Koivurova as a national editor, Natalia Loukacheva and Margherita Paola Poto as associate editors, Njord Wegge as editor for political sciences, and Kristoffer Svendsen as editor for the law of the sea have all made particular contributions. 


\section{The special issue}

This special anniversary volume, available in an open access online format as well as a limited-run hardback edition, comprises 13 different articles, all of which, while invited contributions, were subject to full peer review. As editors of this special issue, we aimed to extend invitations to a broad group of scholars representing a range of subjects and disciplines consistent with the mission of the Review. In some cases, and where appropriate, we asked contributors to include in their article some sense of developments that might have occurred over the life of the journal i.e. over the last ten years. In other cases, such a longitudinal approach was less relevant or indeed covered a longer period. The latter was most obviously the case with respect to the first article in the volume. This article, by Øystein Jensen on the Svalbard Treaty, reflects not only on developments over the last decade, but over the last century. ${ }^{2}$ It seemed particularly important to mark the significant anniversary of that important treaty in this volume. After all, the Svalbard Treaty is one of the few Arctic-specific treaties ever to have been concluded. ${ }^{3}$

Jensen's paper examines the background to the negotiation of the Svalbard Treaty and offers an analysis of its principal terms. The article also traces the development of Norwegian policy with respect to Svalbard and examines current differences between Treaty parties with respect to Norway's interpretation and application of the Treaty. According to Jensen, Norway's policy objectives with respect to Svalbard have been consistent over at least the last 50 years: (1) firm enforcement of sovereignty, (2) proper observance of the Svalbard Treaty and control to ensure compliance, (3) maintenance of peace and stability in the area, (4) preservation of the area's distinctive natural wilderness, and (5) maintenance of Norwegian communities in the archipelago. As for disputes, the principal point of difference between the parties pertains to the area of application of the Treaty. While Norway takes the view that the Treaty only applies to the land area of Svalbard plus the territorial sea, several other parties contend that the privileges and disciplines of the Treaty also apply to Svalbard's other maritime zones. Jensen also touches on elements of the on-going snow crab dispute between Norway and some treaty parties. Norway takes the view that snow crab, as a sedentary species, constitute a resource of the Norwegian continental shelf and thus should be reserved exclusively for Norwegian fishers. Others, principally some EU member States, take the view that snow crab should be treated as a fishery resource.

The ongoing and multifaceted snow crab dispute is also the focus of Tore Henriksen's paper. The starting point for Henriksen's paper is the observation that the snow crab is a relatively new arrival to the Barents Sea. This raises questions as to the rights and duties of states under the law of the sea to exploit, manage and conserve the species. Henriksen discusses three such questions. First, he addresses (in somewhat more detail than Jensen) the question of whether the snow crab qualifies as a sedentary species, or whether it is a species living in the water column. A second 
question is what international obligations, if any, Norway might have as a coastal State in respect of the snow crab. This includes a discussion of the obligations that Norway might have if the snow crab qualifies as an introduced, alien species, or if it arrived by itself through migration. Henriksen also addresses Norway's potential obligations to cooperate insofar as the snow crab resource is shared with Russia. Finally, the article also addresses the implications of the Svalbard Treaty for the snow crab "fishery". Here, Henriksen traces in some detail the various fora in which this issue is being addressed. These fora include domestic proceedings in the Norwegian courts resulting from vessel arrests, as well as ongoing proceedings under the bilateral investment treaty between Norway and Latvia.

Fish and other marine resources are also the focus of three other contributions in this volume. The first of these is Geir Hønneland's paper on the Marine Stewardship Council (MSC) and the certification of Arctic fisheries. In his paper Hønneland addresses the question of how the certification of fisheries according to private sustainability standards (ecolabelling) may contribute to effective fisheries management. Drawing in part upon some of his own experiences as an assessor within the MSC system, Hønneland focuses on the MSC's Fisheries Standard as the major global ecolabel in terms of comprehensiveness and coverage. Reviews under the MSC Standard assess the status of the fishery's target stocks, its impact on the wider ecosystem and the effectiveness of its management system. Hønneland's contribution examines the application of the standard to two clusters of fisheries in Arctic waters, the cod and haddock fisheries of the Barents Sea and the smaller scale lumpfish fisheries in Greenland, Iceland and Norway. He offers practical examples of how application of the MSC Standard has actually resulted in changed practices. In the Barents Sea cod and haddock fisheries, the main obstacle to certification has been the impact of the fishery on endangered, threatened and protected species and bottom habitats. In order to remain certified beyond the first five-year certification period, the fishing companies have had to introduce a number of voluntary measures beyond what is required by law. In the local lumpfish fisheries in Greenland, Iceland and Norway, conditions to certificates have been related to the effects of these fisheries on seabirds and marine mammals. In this case, essential parts of a management regime, such as biological reference points and harvest control rules, have come about as a direct result of MSC certification. This allows Hønneland to conclude that while MSC certification is no panacea, it has "found a niche as a supplement to national legislation and international agreements."

Irene Dahl's paper offers a case study of the legal regulation of the transboundary salmon fishery on the Tana River shared by Norway and Finland. Dahl examines a range of different instruments including the provisions of the Law of the Sea Convention dealing with anadromous stocks as well as the Convention on Biological Diversity and the regional Convention for the Conservation of Salmon in the North Atlantic Ocean (NASCO Convention). A particular focus is the bilateral Agreement between Norway and Finland on fishing in the Tana Watercourses (Tana River 
Agreement), adopted 9 April 2016, entered into force 5 January 2017. However, since Tana River salmon are harvested by Sámi in both countries, Dahl also examines the relevance of the International Labour Organization's Convention Tribal and Indigenous Peoples (ILO C-169) (Norway has ratified this instrument, Finland has not). A main focus of the Tana River Agreement is on the protection of salmon stocks from over exploitation, but Dahl questions whether Norway fulfilled it duty to consult obligations under ILO C-169 in entering into the Agreement as well as whether the Agreement really protects Sámi fishing rights, or is indeed more protective of the fishing rights of Finnish holiday home owners.

The contribution of Vito De Lucia and Philip Peter Nickels takes us beyond fishery resources to a consideration of ongoing efforts to establish an international legally binding instrument on the conservation and sustainable use of marine biological diversity in areas beyond national jurisdiction. The authors note that such an instrument, if adopted, will apply to biological resources in those parts of the Arctic Ocean that lie beyond national jurisdiction (BBNJ). This leads to the question of what role the Arctic Council will play vis-à-vis such a treaty given that the terms of reference for these negotiations anticipate that such a treaty should not "undermine existing relevant legal instruments and frameworks and relevant global, regional and sectoral bodies." The article discusses possible meanings of the notion of not undermining and, more broadly, how a future treaty will likely regulate its institutional relationship with such relevant bodies. More specifically the article explores whether the Arctic Council would qualify as a relevant regional body that is not to be undermined by the anticipated agreement. While the article cannot offer definitive guidance on these points, given the ongoing nature of the BBNJ negotiations, the authors do offer several suggestions as to how possible BBNJ institutions might interact with the Arctic Council and its subsidiary bodies, particularly with respect to the production of scientific knowledge and the designation of marine protected areas in areas beyond national jurisdiction.

In addition to Dahl's paper that covers both fishery issues and the rights of Indigenous peoples, no less than six papers in this anniversary volume address questions of Indigenous rights. The first of these, by Kristina Labba, develops a methodological approach for developing the field of Indigenous law, specifically Sámi law. Labba's account draws on a methodological approach for identifying Indigenous law developed by scholars associated with the Faculty of Law at the University of Victoria, Canada. Labba seeks to apply that methodology to help identify Sámi law. Drawing on the work of Napoleon and Friedland, Labba describes a four-phase methodology: (1) identify a specific research question, (2) interrogate or analyse different sources of law (which may include stories as well as other sources such as songs, dances and art, kinship relationships, place names, and in the structures and aims of institutions), (3) establish a framework for analysis, and (4) implement, apply and engage in critical analysis. Labba's overall conclusion is that it should be possible to apply this framework within Sámi communities. In particular, she suggests that, in 
addition to stories, researchers should be able "to identify legal meanings through Sámi linguistic processes, documentation of knowledge of elders and other community members, and traditional yoiks."

The two papers by Nigel Bankes and Øyvind Ravna as the editors of this volume deal with the status of the duty to consult and the duty of the state to obtain free and prior informed consent (FPIC) of Indigenous communities in Canada and Norway. Originally conceived of as a single comparative article following earlier collaborative work ${ }^{4}$ the differing conceptual and juridical underpinnings of these two duties within each of the two national legal systems made it difficult to apply a common approach. As a result, we have two separate articles with some comparative commentary. As Ravna's account demonstrates, the duty to consult in Norwegian law has its origins in an appreciation of Norway's obligations flowing from its ratification of ILO C-169. By contrast, Canada developed its doctrinal rules with respect to the duty to consult and accommodate as a response to the constitutional protection of Indigenous rights in 1982 and without any reference to international norms. Furthermore, while the duty to consult in Norway has principally been elaborated by means of a political agreement between the government of Norway and the Sámi, the duty to consult in Canada has largely been elaborated by the courts.

David Wright's contribution examines the dispute resolution provisions of comprehensive land claims agreements in Canada. Land claims agreements, often referred to as "modern treaties" are agreements between Indigenous communities and other levels of government dealing with issues of Indigenous title as well as a range of other matters including co-management arrangements for different resources and government functions. As long-term relational agreements, these agreements contain a variety of different dispute resolution provisions. Wright's article reflects on the similarities and differences between these provisions in the different agreements. $\mathrm{He}$ observes that there has been an evolution in these provisions from a relatively narrow arbitration board model to a more flexible "staged approach" involving a broader suite of dispute resolution process options such as negotiations and mediation. $\mathrm{He}$ suggests that such a staged approach may provide a stronger basis for joint problem-solving and integrative bargaining. Wright also draws attention to the conspicuous absence of dispute resolution mechanisms that accommodate, let alone require, approaches rooted in traditional or cultural practices of Indigenous treaty parties. He also describes a law and policy context in contemporary Canada that may be conducive to amending these treaties and dispute resolution practices.

Dorothée Cambou's contribution analyses how the rights of the Sámi to engage in reindeer husbandry are guaranteed in the green transition to renewable energy in Sweden, specifically in the context of the development of wind farms. Drawing on the literature on just transitions (which references distributional, procedural and recognition considerations), Cambou examines the distributive effects of the development of wind energy on reindeer husbandry and identifies the extent to which Sámi reindeer herders are included, and their status and human rights as an indigenous 
people recognised, within this process. Cambou's main conclusion is that Sweden lacks adequate administrative mechanisms to ensure the effective participation of Sámi and more generally suggests that existing measures create institutional restrictions that limit Sámi inclusion in the transition to sustainable development. Judicial supervision of these processes has not rectified this imbalance. The judiciary supports a status quo that benefits the development of wind energy but also perpetuates inequalities because the court decisions implement laws and policies that misrecognise the specific status and rights of Sámi reindeer herders.

Ekaterina Zmyvalova's contribution examines recent developments concerning the human rights of Indigenous small-numbered peoples in Russia. Zmyvalova observes that while Russia's formal legal system contains norms providing for the protection of indigenous small-numbered peoples' rights, Indigenous smallnumbered peoples face multiple challenges when it comes to the implementation of those rights. Zmyvalova identifies four particular issues for further discussion. The first issue deals with the legal attribution of individual members of indigenous communities to indigenous small-numbered peoples. The concern here is that eligible persons may not receive the benefits to which they are entitled but also that census information may be used to eliminate peoples from the official list of indigenous smallnumbered peoples. A second concern relates to the introduction of the notion of 'foreign agent' in Russian legislation in 2012. The law requires an NGO that receives foreign funding and that engages in political activity within Russia to register and imposes other restrictions on the activities of such entities. The definition of foreign agent is broad enough to include both Indigenous organizations and even Indigenous individuals. The breadth of this definition as well as the breadth of the definition of political activities has led to considerable uncertainty and to a chilling effect on those engaged in political activities. A third concern relates to the more general pressure asserted by the State against independent Indigenous organizations. Finally, there are concerns as to the implications of constitutional amendments adopted in 2020. One of the amendments appears to confer on Russian speakers a constitutional primacy in relation to other peoples of the federation. A further amendment serves to render decisions of international treaty bodies and courts subservient to domestic law.

As noted in Ravna's reflections on the first ten years of publishing, the Arctic Review, in addition to providing significant coverage of Indigenous issues in the Arctic has also consistently covered security issues in the Arctic. It is therefore fitting to include in this anniversary issue Njord Wegge's article on the security strategies of key Arctic and North-Atlantic states, namely: the USA, Canada, Denmark, Norway, the UK, Germany and France. Set against a background that includes an outward-looking Russia, as well as the rise of China as a global superpower, Wegge seeks to enhance our understanding of how national Arctic security policies are developing. Wegge identifies similarities but also significant differences among the Arctic and North-Atlantic states. While the US continue to articulate a rather unique 
global perspective in its security strategies for the region, the British, Norwegian, Danish and Canadian perspectives are more regional in nature. Germany maintains a rather low profile in its approach to Arctic security issues compared to its economic status in Europe. France, however, reveals a strong concern for Arctic shipping and freedom of navigation, a perspective not very different from that of the USA, albeit with less global ambition.

In the final article in the volume Jan Solski traces the developments that have occurred in Russian law, policy and practice in relation to the Northern Sea Route (NSR) over the last decade. He observes that it has been a busy decade. It began with the first shipping season to feature the international use of the NSR for commercial purposes, followed by a significant reform of the domestic legal regime, as well as the adoption, internationally, of the Polar Code. Traffic has gradually picked up, and although the expectations of a significant surge in trans-Arctic navigation have not materialized, the NSR's annual turnover has grown beyond the old records set by the USSR. While the Russian authorities have struggled to find the optimal means to develop the NSR, the NSR has recently been re-marketed as the Polar Silk Road (PSR), part of the grand Chinese One Belt One Road initiative. Solski concludes that Russia's efforts to liberalize the legal regime of navigation in the NSR over the last decade have been relatively stable. He also notes that there has been a significant improvement in terms of the consistency of Russian legislation with international law. That said, other de facto developments may all lead to cementing the status quo of the NSR as primarily a national line of communication in the Arctic. Furthermore, it remains to be seen whether the NSR, serving as the PSR, turns into a stable and attractive supply chain for China.

\section{NOTES}

1. Arctic Human Development Report (2004), available at https:/oaarchive.arctic-council.org/ handle/11374/51.

2. The Svalbard Treaty was adopted on 9 February 1920.

3. Nigel Bankes and Timo Koivurova, "Legal Systems" in Arctic Human Development Report, 2nd ed, 2015, pp. 221-252 available online here http://norden.diva-portal.org/smash/record. jsf?pid=diva $\% 3 \mathrm{~A} 788965 \&$ dswid $=-3505$

4. Øyvind Ravna and Nigel Bankes, "Recognition of Indigenous Land Rights in Norway and Canada" (2017), 24 International Journal of Minority and Group Rights 70-117. 